精巣腫瘍組織に括ける乳酸脱水素酵素活性と 乳酸脱水酵素アイソザイム

$\begin{array}{ccccc} & \text { 榊 } & \text { 原 } & \text { 尚 } & \text { 行 } \\ \text { 北海道大学医学部泌尿器科学教室 } & \text { 坂 } & \text { 下 } & \text { 茂 } & \text { 夫 } \\ \text { (主任: 柳知教授) } & \text { 小 } & \text { 柳 } & \text { 知 } & \text { 彦 }\end{array}$

\title{
TOTAL LDH ACTIVITIES AND LDH ISOZYME PATERNS IN THE TISSUES OF TESTICULAR TUMORS
}

\author{
Naoyuki Sakakibara, Shigeo Sakashita and Tomohiko Koyanagi \\ Department of Urology, Hokkaido University School of Medicine, Sapporo, Japan \\ (Director: Prof. T. Koyanagi)
}

The total LDH activities and LDH isozymes were measured in 6 normal testicular tissues and 11 seminoma tissues. The total LDH activities of seminoma tissues were $3778.4 \pm 3674.7 \mathrm{~W} . \mathrm{U} . / \mathrm{mg}$ protein (mean \pm S.D.), significanlty higher than those of mormal testicular tissues $(787.2 \pm 502.4$ W.U./mg protein) ( $\mathrm{p}<0.05$ ). In normal testicular tissues, 5 isozymes (from LDH1 to 5 ) and LDHX were detected, but in semimona tissues only 5 isozymes were detected and LDHX was not detected. In senimoma tissues, compared with normal tissues, LDH1 and LDH2 were elevated. Since it is widely accepted that LDHX appears in primary spermatocytes, these data suggest that the cells of semimoma are composed of less differentiated cells than spermatogonia.

\begin{abstract}
要旨：正常精巣組織 6 例と精上皮腫組織11例の LDH 活性值および LDH アイソザイム分布を測定し

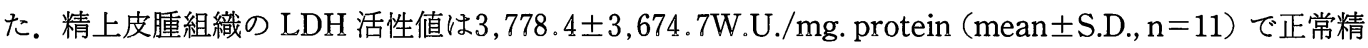
巣組織の LDH 活性值, 787.2 $\pm 502.4 \mathrm{~W} . \mathrm{U} . / \mathrm{mg}$. protein (mean \pm S.D., $\mathrm{n}=6$ )に比して有意に高值であっ た $(\mathrm{p}<.05)$. 正常精巣組織には LDH1～LDH5末での 5 つのアイソザイムと LDHX がみとめられたが， 精上皮腫組織では LDH1ＬDH5 てでの 5 のアイソザイムのみで LDHX はみられなかった。精上皮腫組 織では正常精巣組織に比して LDH1と LDH2の 2 つのイソザイムが上昇していた. LDHX は精巣に第 1 次精母細胞が出現する時期よりみられることより，精上皮腫は第 1 次精母細胞より未分化な精細胞が 癌化したものと考えられた。
\end{abstract}

\section{緒 言}

酵素化学領域では普遍的な酵素の 1 つにあげられる 乳酸脱水素酵素 lactate dehydrogenase (以下 LDH と略す)は, 悪性腫瘍患者に执いて血清 LDH 活性が上 昇することより。悪性腫瘍の非特異的マーカーとして 臨床上広く用いられている。血清 LDH は電気泳動法 で易動度の速いもの（陽極側）から順に, LDH1から LDH5までの 5 のアイソザイムがあることが知られて

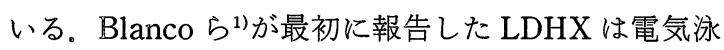
動法で LDH3と LDH4の間に泳動する酵素で, 思春期 以降の精巣組織と精液にのみ認められ, それ以外の臓 器, 体液中にはみとめられない。このことより LDHX
は精子生成に関与した特異な酵素と考兄られ, 男子妊 孕能と関連ずけた研究が広く行なわれている。

この LDHX と分化した精細胞由来とされている精 上皮腫との関連性について詳しい検討はされていな い. LDHX と精上皮腫について研究することは精上皮 腫の病因について考案する 1 つ手段となると考光, ヒト精上皮腫組織とヒト正常精巣組織を用いて LDH 活性预よび LDH アイソザイム分布測定を行なった。

\section{対象}

ヒト正常精巣組織およびヒト精上皮腫組織を用い た.

1）正常精巣組織：除辠術を施行した前立腺癌症例 
5 例（年柃63歳から87歳）の精巣組織と高位除悬術を 施行した精上皮腫症例（24歳）の正常組織部分の計 6 例を用いた。

2）精上皮腫組織：高位除辠術を施行した精上皮腫 患者11症例 (年齢21歳から48歳) の腫瘍組織を用いた。

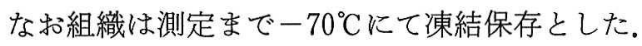

\section{方法}

正常精巣組織おうよ゙精上皮腫組織は容量比 5 倍量の 生食を加壳たのち Potter 型 homogenizer で懸濁液を 作成し，懸濁液を $3,000 \mathrm{rpm}$ で遠沈して，その上清の LDH 活性, LDH アイソザイム分布, 蛋白定量をそれ ぞれ測定した。

1） LDH 活性：LDH 活性は NADH に基質緩衝液 を加光て LDH 測定液を作成した後, 試験管にこの $\mathrm{LDH}$ 測定液 $2 \mathrm{ml}$ と組織懸濁液上清 $0.05 \mathrm{ml}$ を加光ただ ちに試験管の内容を層長 $10 \mathrm{~mm}$ の七ルに移し, 分光光 度計で $340 \mathrm{~nm}$ の吸光度の減少をみることにより算出 した．尚，測定に際しては同一のサンプルについて二 度同様の操作を抗こないその平均を $\mathrm{LDH}$ 活性とし た。

2) LDH アイソザイム分布：LDH アイソザイムは 寒天ゲルプレートにウルトラマイクロピペットを用い て組織懸濁液上清を塗布し, 定電流 $(30 \mathrm{~mA})$ で泳動時 間 1 時間の電気泳動を行なったのち基質緩衝液を加兄 た発色剂 (LDH isozyme Wako) を寒天ゲルプレート 表面に流し込み, $37^{\circ} \mathrm{C}$ 遮光孵卵器中で 60 分反応させた。 反応終了後, 未反応液をすて脱色固定液(エタノール： 水：氷酶酸を $14 ： 5 ： 1$ ) に20分間浸漬し未反応色素 がなくなるまでゆり動かしながら浸漬させたのら水道 水で水洗した。 この後, 寒天ゲルプレートを乾燥させ, デンシトメーターにかけLDH アイソザイム分布を測 定した。波長は570nm で測定した。

3）蛋白定量測定：組織懸濁液上清の蛋白定量は牛 血清アルブミンを用い標準曲線を作成し, Lowry 法2) により測定した。

$$
\text { 結 果 }
$$

1) LDH 活性: 正常精巣組織の LDH 活性值は 169.7 1,603.4W.U./mg. protein で, 平均値土標準偏 差值は (mean \pm S.D.) 787.2 $\pm 502.4 \mathrm{~W} . \mathrm{U} . / \mathrm{mg}$. protein であった。一方, 精上皮腫組織の LDH 活性值は 1,363.7 107,533.0W.U./mg. protein で, mean \pm S.

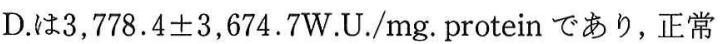
精巣組織の LDH 值に比して有意に高值であった $(\mathrm{p}<.05)($ 表 1 ).
表 $1 \quad$ LDH 活性値

\begin{tabular}{c|c}
\hline 組 織 & $\begin{array}{c}\text { 活 性 值 } \\
\text { (W.U./mg. protein) }\end{array}$ \\
\hline $\begin{array}{c}\text { 正常精巣組織 } \\
(\mathrm{n}=6)\end{array}$ & $787.2 \pm 502.4$ \\
\hline 精 $\begin{array}{c}\text { 上 皮 } \\
(\mathrm{n}=11)\end{array}$ & $3778.4 \pm 3674.7$ \\
\hline
\end{tabular}

$(\mathrm{p}<0.05)$

表 2 LDH アイソザイム分布

\begin{tabular}{c|c|c|c|c|c|c}
\hline LDH isozyme(\%) & 1 & 2 & 3 & $\mathrm{X}$ & 4 & 5 \\
\hline $\begin{array}{c}\text { 正常精巣組織 } \\
(\mathrm{n}=1)\end{array}$ & 4.6 & 15.5 & 19.7 & 24.4 & 27.6 & 8.2 \\
\hline 精 $\frac{\text { 上 皮 }}{(\mathrm{n}=2)}$ & 39.1 & 30.2 & 19.5 & 0 & 10.0 & 1.2 \\
\hline
\end{tabular}

因 1 精上皮腫組織を正常精巣組織の LDH アイソザ イム

正常組織にみられる LDHX が精上皮腫組織では消 失している.
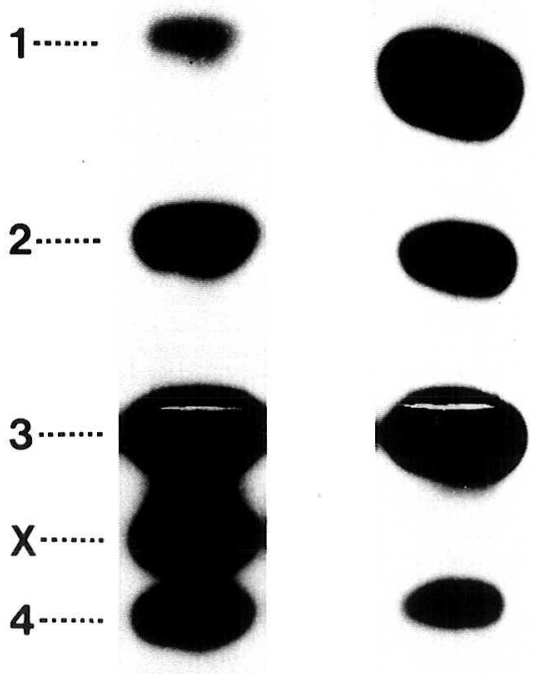

5

$5 \cdots \cdots$

\section{Normal Testis Seminoma}

2）LDH アイソザイム分布：正常精巣組織の LDH アイソザイム分布は 6 例全例, LDH1から LDH5まで の 5 のアイソザイムと LDHX の 6 つのアイソザイム が認められたが，精上皮腫組織は11例全例とも LDH1 から LDH5\&での 5 のアイソザイムのみで LDHX は 
認められなかった。このうち正常精巣組織 1 例と精上 皮腫組織 2 例について LDH アイソザイム分布をみ た。正常精巣組織は LDH1 4.6\%，LDH2 15.5\%, LDH3 19.7\%, LDHX 24.4\%, LDH4 27.6\%, LDH5 $8.2 \%$ であった。精上皮腫組織 2 例の平均は， LDH1 39.1\%, LDH2 30.2\%, LDH3 19.5\%, LDH4 10.0\%, LDH5 1.2\%で LDHX は認められなかった（表 2，図 $1)$.

\section{考案}

乳酸脱水素酵素アイソザイムXは，1963年 Blanco ら゙により最初に報告された特異な酵素で，思春期以 降の精巣組織と射精液中にのみ見られるとされてい る. 精巣組織においては第一次精母細胞の出現と同時 にみられるようになること，精子の LDH 活性の $100 \%$ が LDHX の活性であるともいわれている314) ことから 精子生成能の指標とされ研究されている。

精上皮腫は発生学的には分化した精細胞の癌化した ものと考光られているが，他の精巣 germinal cell tumorにみられるような AFP, HCG といった特異的 マーカーはなく, 血清 LDH 活性が高值となる症例が 多いことと一部の症例で血中 HCG 值が高值となるこ とが知られているのみで精上皮腫に特異的なマーカー はみられず診断拉よび治療上病態の把握に苦慮する場 合がある。この精上皮腫の組織レベルに打ける LDH 活性値と精子生成に関与しているとされている LDHX の存在の有無についての研究はされていない.

精上皮腫症例の血清 LDH 活性值がしばしば高值を とることはよく知られているが，今回の検討に揖いて も正常精巣組織の LDH 活性值が787.2 5502.4 W.U./ mg. protein (mean \pm S.D.) であったのに対し精上皮腫 組織の LDH 活性値は3,778.4 $43.674 .7 \mathrm{~W} . \mathrm{U} . / \mathrm{mg}$. protein (mean \pm S.D.) と正常精巣組織の LDH 活性値 に比して有意に高値を呈した $(\mathrm{p}<.05)$ 。このことは腫 瘍細胞の解糖能の六進を示しているものと思われる. また, 精上皮腫の腫場重量は $5 \sim 1,500 \mathrm{~g}$ と幅広い分布 を呈したが，腫瘍重量と LDH 活性值，また病期と LDH 活性値との間には相関は認めなかった。このう ち24歳男子の精上皮腫症例の正常部拈よび腫瘍部の組 織中の LDH 活性值はそれぞれ567.3W.U./mg. protein. 3,381.3mg. protein, で腫瘍部の組織の方が明ら かに LDH 活性值は高值であった。

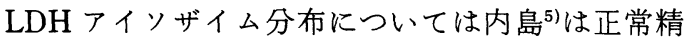

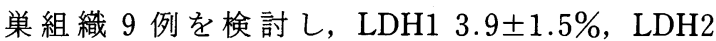
$20.2 \pm 2.6 \%$, LDH3 $33.8 \pm 4.3 \%$, LDHX $18.7 \pm$

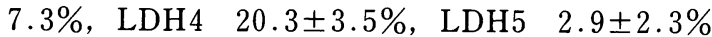
（mean \pm S.D.）であったとしている報告と本検討の正 常精巣組織の LDH アイソザイム分布は注注同様の傾 向であった。一方, 精上皮腫組織 2 例の LDH アイソザ 1.ム分布は LDH1 39.1\%, LDH2 30.2\%, LDH3 19.7\%, LDH4 10.0\%, LDH5 1.2\%で LDHX はみら

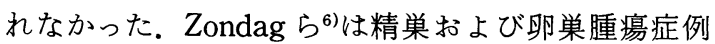
（精上皮腫 9 例を含む）の血清 $\mathrm{LDH}$ 活性と血清 $\mathrm{LDH}$ アイソザイム分布を検討し, 総血清 LDH 活性值の上 昇および血清 $\mathrm{LDH}$ 分布において LDH1のみあるいは LDH1と LDH2が上昇しているものが15例中13例にみ られたと報告している。精上皮腫の組織中の LDH ア イソザイム分布についての詳しい検討はされていな い，本検討に打いては精上皮腫組織中に扔いて，総 $\mathrm{LDH}$ 活性値の上昇が認められ，2 例と症例数は少な いがLDH アイソザイム分布においてはLDH1および LDH2が上昇することが示唆された。精巣腫瘍組織に おいてLDHX がみられないことはHoag らが精巣 胎児性癌組織 1 例の LDH アイソザイム分布を測定し 報告している。しかしながら，精上皮腫組織を用いて LDHX の有無について検討された報告はみられない。 本検討において精子生成能に関与し, 第 1 次精母細胞 出現と同時にみられるようになる LDHX が精上皮腫 では消失していた。このことは分化した精母細胞由来 とされている精上皮腫の発生起源は第 1 次精母細胞よ り末分化な段階であろらと推測される.LDHX の消失 の機序は不明であろるが, 精巣腫瘍患者は治療前すで に妊孕能が低下していること采，妊孕能が低下してい るとされている停留辡丸に腫瘍の発生頻度が高いこと などを考兄合わせていくと, LDHX の機能的役割の解 明がすすむとともに明らかになっていくものと拈もわ れる。しかしながら, 癌化により LDHX の電荷性が变 化し他のアイソザイムと同じ様な電気易動性となった ためにLDHX が消失している様にみえたことも考兄 られ，さらに詳細な検討が必要と打もわれた。

\section{結語}

正常精巣組織 6 例, 精上皮腫組織11例を用いて LDH 活性值およびLDH アイソザイム分布を測定し た.

1) LDH 活性值は, 正常精巣組織では787.2士 3,674.7W.U./mg. protein (mean \pm S.D., $\mathrm{n}=6$ ) で, 精上皮腫組織では3,778.4 $\pm 3,674.7$ （mean \pm S.D., $\mathrm{n}=11$ ) であり, 精上皮腫組織の LDH 活性は正常精巣 組織の LDH 活性に比して有意に高值であった 
$(\mathrm{p}<.05)$.

2) LDH アイソザイム分布は, 正常精巣組織では LDH1〜LDH5までの 5 つのアイソザイムと LDHX がみられたが, 精上皮腫組織では LDH1〜LDH5まで の 5 のアイソザイムのみでLDHX はみられなかっ た. また精上皮腫組織では LDH1と LDH2のアイソザ イムが正常精巣組織に比して上昇していた。

3）精上皮腫組織に扔いて LDHX が消失している ことょり精上皮腫は第 1 次精母細胞以前の段階の精細 胞の癌化したものと推測された。

\section{文献}

1) Blanco, A. and Zinkham, W.H.: Lactate dehydrogenase in human testes. Science, 139 , 601-602, 1963.

2) Lowry, O.H., Rosebrough, N.J., Farr, A.L. and Randall, R.J.: Protein measurement with the folin phenol reagent. J. Biol. Chem., 193, 265-275, 1951.

3) Clausen, J. and Ovlisen, B.: Lactate dehy- drogenase isozymes of human semen. Biochem. J., 97, 513-517, 1965.

4) Clausen, J.: Lactate dehydrogenase isozymes of sperm cells and testes. Biochem. J., 111, 207-218, 1969.

5）内島 豊：ヒト射精液中の乳酸脱水素酵素とその アインザイム．日泌尿会誌，72，643-661，1981.

6) Zondag, H.A. and Klein, F.: Clinical applications of lactate dehydrogen ase isoenzymes: Alternations in malignancy. N.Y. Acad. Sci., 151, 578, 1968.

7) Hoag, G., Amies, D.R. and Colquhoun, B.D.P. : The production of creatine kinase isozyme $\mathrm{BB}$ in sera of a patient with prostatic carcinoma and in tumor homogenates. Clin. Biochem., 11, $38-41,1978$.

8）古畑哲彦, 小川勝明, 穂坂正彦, 菅原敏道：辠丸腫 瘍患者の治療後の辠丸機能に関する研究一第 1 編. 治療前後の妊孕性について一. 日泌尿会誌, 76, 1022-1088, 1985.

（昭和61年 4 月 5 日受付） 